\title{
Conservation genomics reveals multiple evolutionary units within Bell's Vireo (Vireo bellii)
}

\author{
Luke B. Klicka ${ }^{1,2} \cdot$ Barbara E. Kus ${ }^{3} \cdot$ Pascal O. Title ${ }^{4} \cdot$ Kevin J. Burns $^{1}$
}

Received: 29 May 2015/Accepted: 19 November 2015/Published online: 25 November 2015

(c) The Author(s) 2015. This article is published with open access at Springerlink.com

\begin{abstract}
The Bell's Vireo (Vireo bellii) is a widespread North American species of bird that has declined since the mid-1960s primarily due to habitat modification. Throughout its range, Bell's Vireo populations are regulated under varying degrees of protection; however, the species has never been characterized genetically. Therefore, the current taxonomy used to guide management decisions may misrepresent the true evolutionary history for the species. We sequenced 86 individuals for ND2 and genotyped 48 individuals for genome-wide SNPs to identify distinct lineages within Bell's Vireo. Phylogenetic analyses uncovered two distinct clades that are separated in the arid southwestern United States, near the border of the Chihuahuan and Sonoran Deserts. These clades diverged from each other approximately 1.11-2.04 mya. The timing of diversification, geographic location, and niche modeling of the east/west divergence suggest vicariance as a mode of diversification for these two lineages. Analyses of the SNP dataset provided additional resolution and indicated the
\end{abstract}

Electronic supplementary material The online version of this article (doi:10.1007/s10592-015-0796-z) contains supplementary material, which is available to authorized users.

Luke B. Klicka

klicks87@gmail.com; klicka@ku.edu

1 Department of Biology, San Diego State University, 5500 Campanile Drive, San Diego, CA 92182, USA

2 Present Address: University of Kansas Biodiversity Institute, 1345 Jayhawk Blvd, Lawrence, KS 66049, USA

3 U.S. Geological Survey, Western Ecological Research Center, 4165 Spruance Rd, Suite 200, San Diego, CA 92101, USA

4 Department of Ecology and Evolutionary Biology, University of Michigan, Ann Arbor, MI 48109, USA
Least Bell's Vireo populations are a distinct evolutionary lineage. Our genetic evidence, together with information from morphology and behavior, suggests that the Bell's Vireo complex involves two species, each containing two separate subspecies. This new information has implications for the federal, state and other listing status of Bell's Vireo throughout its range.

Keywords Conservation - Genomics · Phylogeography · Vireo bellii $\cdot$ Population genetics

\section{Introduction}

Bell's Vireo (Vireo bellii) is a species of conservation concern throughout its U.S. range. An inhabitant of some of North America's most threatened habitat types, including riparian and grassland-shrub habitats, Bell's Vireo has declined at a rate of approximately $2.7 \%$ per year since the mid-1960s (Sauer et al. 2008). Habitat modification associated with agriculture, grazing, urbanization, flood management and wildfire has destroyed, degraded and fragmented vireo breeding habitat, while brood parasitism by the Brown-headed Cowbird (Molothrus ater) has exacerbated population declines triggered by habitat loss (Kus et al. 2010). In California, precipitous declines of $V$. b. pusillus (Least Bell's Vireo) during the latter part of the twentieth century prompted the listing of this subspecies as state and federally endangered (Franzreb 1989; Goldwasser et al. 1980). V. b. arizonae is state endangered in California and state threatened in New Mexico, V. $b$. medius is state threatened in New Mexico, and $V . b$. bellii is state threatened in Minnesota. In the rest of the U.S., Bell's Vireo is identified as a high priority conservation target by the Audubon Society's "Red Watchlist" of species of highest 
national concern, and by Partners in Flight U.S. as a "Bird of Conservation Concern" in 14 Bird Conservation Regions. Thus, a variety of federal and state laws, as well as non-governmental programs, guide the conservation of Bell's Vireo throughout its range.

Current taxonomy of Bell's Vireo recognizes four subspecies distributed from central and southwestern U.S. to northern Mexico (Fig. 1), but these subspecies designations are based solely upon qualitative morphological differences in plumage coloration and tail length described in the late 1800s and early 1900s (Ridgway 1904). Although other species of vireo have been studied genetically (Zwartjes 1999, 2001, 2003), no previous genetic studies have focused on the Bell's Vireo, despite its conservation significance. Species or subspecies delimited solely on the basis of non-genetic data can mislead conservation efforts by misrepresenting the underlying intraspecific variation and evolutionary history (Zink 2004). The advent of modern molecular genetic techniques makes it possible to re-assess the intraspecific classification of Bell's Vireo and evaluate concordance between phylogenetic patterns of genetic variation and the existing morphologically based
Fig. 1 Sampling locations for Bell's Vireo and median-joining network for ND2 for 86 Bell's Vireo individuals. Shaded area indicates breeding distribution. Mutational steps between sampled haplotypes are indicated with grey circles. The branch connecting the eastern and western clades (broken branch) represents 27 mutational steps. Circle size is proportional to the number of individuals sharing that haplotype with the largest western haplotype representing 21 individuals and the largest eastern haplotype representing 9 individuals. The starred locality indicates the western individual MBM 13821. Letters indicate population groupings (Table 1) and colors represent the four subspecies: red V. b. pusillus, black $V . b$. arizonae, blue $V . b$. medius, yellow $V$. b. bellii and three black lines indicate approximate boundaries between subspecies. $A Z$ Arizona, $C A$ California, $M N$ Minnesota, $M O$ Missouri, $M X$ Mexico, $N D$ North Dakota, $N M$ New Mexico, $N V$ Nevada, $O K$ Oklahoma, $T X$ Texas
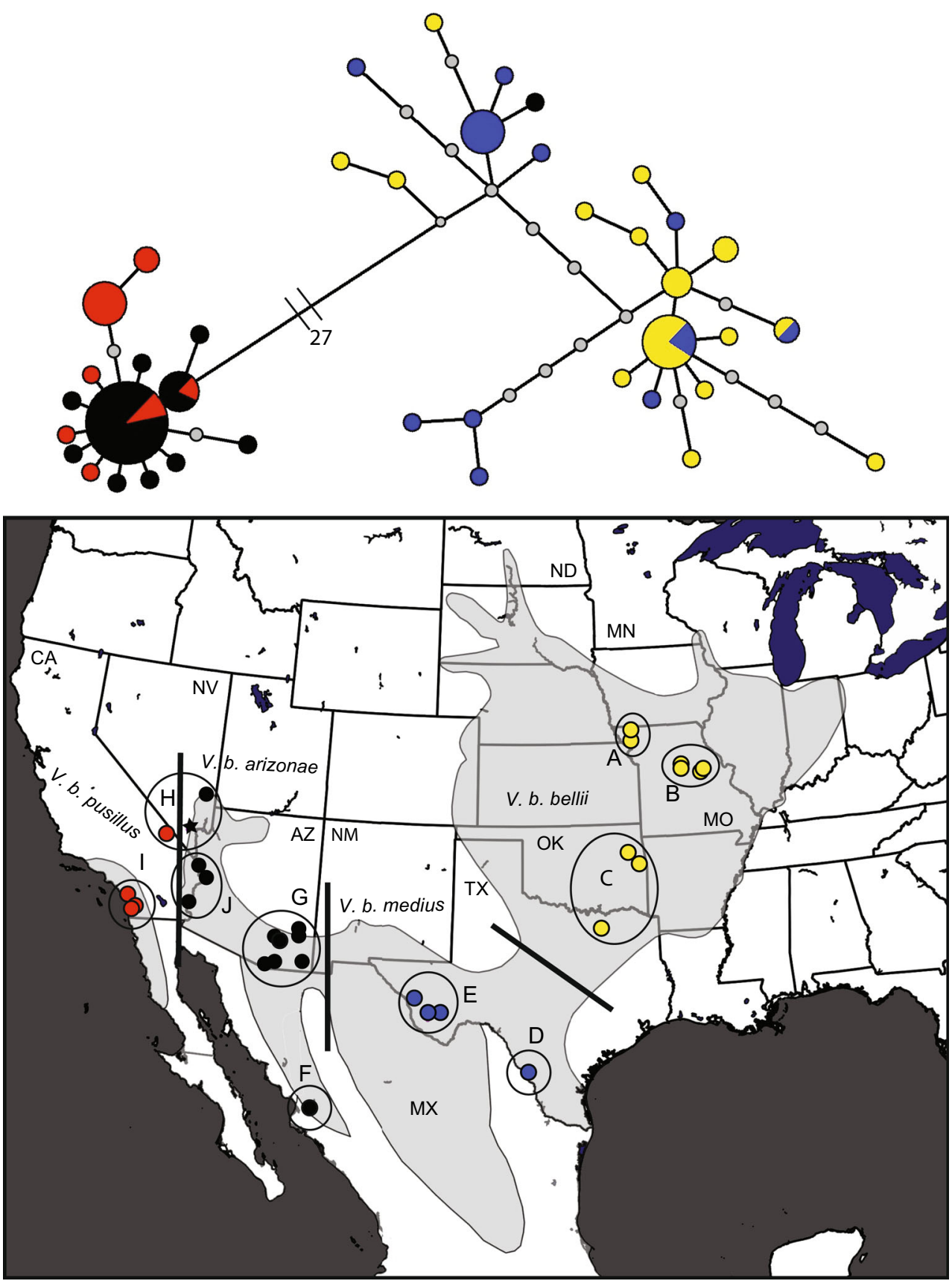
Table 1 Specimens are grouped by current taxonomy and then alphabetized by institution

\begin{tabular}{|c|c|c|c|c|c|c|c|c|}
\hline $\begin{array}{l}\text { Current } \\
\text { Taxonomy }\end{array}$ & $\begin{array}{l}\text { Proposed } \\
\text { Taxonomy }\end{array}$ & Museum & Tissue & Locality & Latitude & Longitude & Fig. 3 & Group \\
\hline V. bellii bellii & V. bellii bellii & ANSP & 17777 & USA: MO, Nodaway Co. & 40.34770 & -94.87196 & 28 & $\mathrm{~A}$ \\
\hline V. bellii bellii & V. bellii bellii & KU & 89925 & USA: MO, Holt Co. & 40.1 & -95.05 & 20 & A \\
\hline V. bellii bellii & V. bellii bellii & KU & 89926 & USA: MO, Holt Co. & 40.1 & -95.05 & 20 & $\mathrm{~A}$ \\
\hline V. bellii bellii & V. bellii bellii & MVZ & 178222 & USA: OK, Sequoyah Co. & 35.4262 & -94.88121 & 24 & $\mathrm{C}$ \\
\hline V. bellii bellii & V. bellii bellii & SDSU & 2925 & USA: MO, Callaway Co., Reform & 38.75568 & -91.78078 & 33 & $\mathrm{~B}$ \\
\hline V. bellii bellii & V. bellii bellii & SDSU & 2926 & USA: MO, Callaway Co., Reform & 38.75568 & -91.78078 & 29 & $\mathrm{~B}$ \\
\hline V. bellii bellii & V. bellii bellii & SDSU & 2927 & $\begin{array}{l}\text { USA: MO, Cooper Co., Overton } \\
\text { Bottoms }\end{array}$ & 38.92480 & -92.52166 & 21 & $\mathrm{~B}$ \\
\hline V. bellii bellii & V. bellii bellii & SDSU & 2928 & USA: MO, Callaway Co., Reform & 38.75568 & -91.78078 & 29 & $\mathrm{~B}$ \\
\hline$V$. bellii bellii & $V$. bellii bellii & SDSU & 2929 & $\begin{array}{l}\text { USA: MO, Cooper Co., Overton } \\
\text { Bottoms }\end{array}$ & 38.92480 & -92.52166 & 36 & $\mathrm{~B}$ \\
\hline V. bellii bellii & V. bellii bellii & SDSU & 2930 & $\begin{array}{l}\text { USA: MO, Cooper Co., Overton } \\
\text { Bottoms }\end{array}$ & 38.92480 & -92.52166 & 23 & $\mathrm{~B}$ \\
\hline V. bellii bellii & V. bellii bellii & SDSU & 2931 & $\begin{array}{l}\text { USA: MO, Cooper Co., Overton } \\
\text { Bottoms }\end{array}$ & 38.92480 & -92.52166 & 29 & $\mathrm{~B}$ \\
\hline V. bellii bellii & V. bellii bellii & SDSU & 2932 & USA: MO, Callaway Co., Reform & 38.75568 & -91.78078 & 20 & $\mathrm{~B}$ \\
\hline V. bellii bellii & V. bellii bellii & SDSU & 2933 & $\begin{array}{l}\text { USA: MO, Cooper Co., Overton } \\
\text { Bottoms }\end{array}$ & 38.92480 & -92.52166 & 30 & $\mathrm{~B}$ \\
\hline V. bellii bellii & V. bellii bellii & SDSU & 2934 & USA: MO, Boone Co., Davisdale & 39.01562 & -92.62389 & NA & $\mathrm{B}$ \\
\hline V. bellii bellii & V. bellii bellii & SDSU & 2935 & $\begin{array}{l}\text { USA: MO, Callaway Co., Whetstone } \\
\text { Creek }\end{array}$ & 38.87036 & -91.73503 & 34 & $\mathrm{~B}$ \\
\hline$V$. bellii bellii & $V$. bellii bellii & SDSU & 2936 & $\begin{array}{l}\text { USA: MO, Callaway Co., Whetstone } \\
\text { Creek }\end{array}$ & 38.87036 & -91.73503 & 32 & $\mathrm{~B}$ \\
\hline V. bellii bellii & V. bellii bellii & SDSU & 2937 & $\begin{array}{l}\text { USA: MO, Callaway Co., Whetstone } \\
\text { Creek }\end{array}$ & 38.87036 & -91.73503 & 20 & $\mathrm{~B}$ \\
\hline V. bellii bellii & V. bellii bellii & SDSU & 2938 & $\begin{array}{l}\text { USA: MO, Callaway Co., Whetstone } \\
\text { Creek }\end{array}$ & 38.87036 & -91.73503 & 20 & $\mathrm{~B}$ \\
\hline V. bellii bellii & V. bellii bellii & SDSU & 2939 & $\begin{array}{l}\text { USA: MO, Callaway Co., Whetstone } \\
\text { Creek }\end{array}$ & 38.87036 & -91.73503 & 20 & $\mathrm{~B}$ \\
\hline V. bellii bellii & V. bellii bellii & SDSU & 2940 & $\begin{array}{l}\text { USA: MO, Callaway Co., Whetstone } \\
\text { Creek }\end{array}$ & 38.87036 & -91.73503 & 25 & $\mathrm{~B}$ \\
\hline V. bellii bellii & $V$. bellii bellii & SDSU & 2941 & $\begin{array}{l}\text { USA: MO, Callaway Co., Whetstone } \\
\text { Creek }\end{array}$ & 38.87036 & -91.73503 & 20 & B \\
\hline V. bellii bellii & V. bellii bellii & UCLA & $06 \mathrm{~N} 30370$ & USA: OK, Wagoner Co. & 35.89166 & -95.3111 & 27 & $\mathrm{C}$ \\
\hline V. bellii bellii & V. bellii bellii & UCLA & 06N30377 & USA: OK, Wagoner Co. & 35.89166 & -95.3111 & 22 & $\mathrm{C}$ \\
\hline V. bellii bellii & V. bellii bellii & UCLA & $08 \mathrm{~N} 21510$ & USA: OK, Wagoner Co. & 35.89166 & -95.3111 & 26 & $\mathrm{C}$ \\
\hline $\begin{array}{l}V . \text { bellii } \\
\text { medius }\end{array}$ & V. bellii medius & LSU & 30896 & USA: TX, Webb Co. & 27.87777 & -99.88527 & 19 & $\mathrm{D}$ \\
\hline $\begin{array}{l}V . \text { bellii } \\
\text { medius }\end{array}$ & V. bellii medius & LSU & 43284 & USA: TX, Webb Co. & 27.87777 & -99.88527 & 40 & $\mathrm{D}$ \\
\hline $\begin{array}{l}V . \text { bellii } \\
\text { medius }\end{array}$ & V. bellii medius & LSU & 47300 & USA: TX, Jeff Davis Co. & 30.63372 & -104.6851 & 16 & $\mathrm{E}$ \\
\hline $\begin{array}{l}V . \text { bellii } \\
\text { medius }\end{array}$ & V. bellii medius & LSU & 47301 & USA: TX, Jeff Davis Co. & 30.63372 & -104.6851 & 39 & $\mathrm{E}$ \\
\hline $\begin{array}{l}V . \text { bellii } \\
\text { medius }\end{array}$ & V. bellii medius & LSU & 51626 & USA: TX, Presidio Co. & 30.57966 & -104.6782 & 35 & $\mathrm{E}$ \\
\hline $\begin{array}{l}\text { V. bellii } \\
\text { medius }\end{array}$ & V. bellii medius & LSU & 56752 & USA: TX, Presidio Co. & 30.57966 & -104.6782 & 39 & $\mathrm{E}$ \\
\hline $\begin{array}{l}V . \text { bellii } \\
\text { medius }\end{array}$ & V. bellii medius & LSU & 64277 & USA: TX, Jeff Davis Co. & 30.63372 & -104.6851 & 39 & $\mathrm{E}$ \\
\hline $\begin{array}{l}V . \text { bellii } \\
\text { medius }\end{array}$ & V. bellii medius & LSU & 64279 & USA: TX, Jeff Davis Co. & 30.63372 & -104.6851 & 39 & $\mathrm{E}$ \\
\hline
\end{tabular}


Table 1 continued

\begin{tabular}{|c|c|c|c|c|c|c|c|c|}
\hline $\begin{array}{l}\text { Current } \\
\text { Taxonomy }\end{array}$ & $\begin{array}{l}\text { Proposed } \\
\text { Taxonomy }\end{array}$ & Museum & Tissue & Locality & Latitude & Longitude & Fig. 3 & Group \\
\hline $\begin{array}{l}\text { V. bellii } \\
\text { medius }\end{array}$ & V. bellii medius & LSU & 64548 & USA: TX, Jeff Davis Co. & 30.63372 & -104.6851 & 18 & $\mathrm{E}$ \\
\hline $\begin{array}{l}V . \text { bellii } \\
\text { medius }\end{array}$ & $V$. bellii medius & LSU & 64549 & USA: TX, Jeff Davis Co. & 30.63372 & -104.6851 & 39 & $\mathrm{E}$ \\
\hline $\begin{array}{l}V . \text { bellii } \\
\text { medius }\end{array}$ & $V$. bellii medius & SDSU & 2912 & USA: TX, Brewster Co. & 30.00358 & -103.5577 & 17 & $\mathrm{E}$ \\
\hline $\begin{array}{l}V . \text { bellii } \\
\text { medius }\end{array}$ & $V$. bellii medius & SDSU & 2913 & USA: TX, Brewster Co. & 29.98336 & -103.5437 & 30 & $\mathrm{E}$ \\
\hline $\begin{array}{l}\text { V. bellii } \\
\text { medius }\end{array}$ & $V$. bellii medius & SDSU & 2914 & USA: TX, Brewster Co. & 30.02398 & -103.5629 & 20 & $\mathrm{E}$ \\
\hline $\begin{array}{l}V . \text { bellii } \\
\text { medius }\end{array}$ & V. bellii medius & SDSU & 2915 & USA: TX, Brewster Co. & 30.0453 & -103.5685 & 39 & $\mathrm{E}$ \\
\hline $\begin{array}{l}V . \text { bellii } \\
\text { medius }\end{array}$ & V. bellii medius & SDSU & 2916 & USA: TX, Brewster Co. & 30.04823 & -103.5705 & 31 & $\mathrm{E}$ \\
\hline $\begin{array}{l}V . \text { bellii } \\
\text { medius }\end{array}$ & $V$. bellii medius & UCLA & $06 \mathrm{~N} 13115$ & USA: TX, Collin Co. & 33.16027 & -96.61944 & 38 & $\mathrm{C}$ \\
\hline $\begin{array}{l}\text { V. bellii } \\
\text { arizonae }\end{array}$ & $\begin{array}{l}\text { V. pusillus } \\
\text { arizonae }\end{array}$ & $\mathrm{MBM}^{\mathrm{a}}$ & 13821 & USA: NV, Clark Co. & 36.07956 & -115.0940 & 37 & $\mathrm{H}$ \\
\hline $\begin{array}{l}\text { V. bellii } \\
\text { arizonae }\end{array}$ & $\begin{array}{l}\text { V. pusillus } \\
\text { arizonae }\end{array}$ & MVZ & 171847 & USA: NV, Lincoln Co. & 37.32294 & -114.535 & 7 & $\mathrm{H}$ \\
\hline $\begin{array}{l}\text { V. bellii } \\
\text { arizonae }\end{array}$ & $\begin{array}{l}\text { V. pusillus } \\
\text { arizonae }\end{array}$ & SDSU & 2881 & $\begin{array}{l}\text { USA: AZ, Mojave Co., Bill Williams } \\
\text { NWR }\end{array}$ & 34.26801 & -114.0657 & 4 & $\mathrm{~J}$ \\
\hline $\begin{array}{l}V . \text { bellii } \\
\text { arizonae }\end{array}$ & $\begin{array}{l}\text { V. pusillus } \\
\text { arizonae }\end{array}$ & SDSU & 2882 & $\begin{array}{l}\text { USA: AZ, Mojave Co., Bill Williams } \\
\text { NWR }\end{array}$ & 34.26801 & -114.0657 & 7 & $\mathrm{~J}$ \\
\hline $\begin{array}{l}\text { V. bellii } \\
\text { arizonae }\end{array}$ & $\begin{array}{l}\text { V. pusillus } \\
\text { arizonae }\end{array}$ & SDSU & 2883 & $\begin{array}{l}\text { USA: AZ, Mojave Co., Bill Williams } \\
\text { NWR }\end{array}$ & 34.26801 & -114.0657 & 14 & $\mathrm{~J}$ \\
\hline $\begin{array}{l}\text { V. bellii } \\
\text { arizonae }\end{array}$ & $\begin{array}{l}\text { V. pusillus } \\
\text { arizonae }\end{array}$ & SDSU & 2884 & $\begin{array}{l}\text { USA: AZ, Mojave Co., Bill Williams } \\
\text { NWR }\end{array}$ & 34.26801 & -114.0657 & 15 & $\mathrm{~J}$ \\
\hline $\begin{array}{l}\text { V. bellii } \\
\text { arizonae }\end{array}$ & $\begin{array}{l}\text { V. pusillus } \\
\text { arizonae }\end{array}$ & SDSU & 2885 & $\begin{array}{l}\text { USA: AZ, Mojave Co., Bill Williams } \\
\text { NWR }\end{array}$ & 34.26801 & -114.0657 & 7 & $\mathrm{~J}$ \\
\hline $\begin{array}{l}\text { V. bellii } \\
\text { arizonae }\end{array}$ & $\begin{array}{l}\text { V. pusillus } \\
\text { arizonae }\end{array}$ & SDSU & 2886 & $\begin{array}{l}\text { USA: AZ, Mojave Co., Bill Williams } \\
\text { NWR }\end{array}$ & 34.26801 & -114.0657 & 14 & $\mathrm{~J}$ \\
\hline $\begin{array}{l}\text { V. bellii } \\
\text { arizonae }\end{array}$ & $\begin{array}{l}\text { V. pusillus } \\
\text { arizonae }\end{array}$ & SDSU & 2887 & $\begin{array}{l}\text { USA: AZ, Mojave Co., Bill Williams } \\
\text { NWR }\end{array}$ & 34.26801 & -114.0657 & 7 & $\mathrm{~J}$ \\
\hline $\begin{array}{l}\text { V. bellii } \\
\text { arizonae }\end{array}$ & $\begin{array}{l}\text { V. pusillus } \\
\text { arizonae }\end{array}$ & SDSU & 2888 & $\begin{array}{l}\text { USA: AZ, Mojave Co., Bill Williams } \\
\text { NWR }\end{array}$ & 34.26801 & -114.0657 & 7 & $\mathrm{~J}$ \\
\hline $\begin{array}{l}\text { V. bellii } \\
\text { arizonae }\end{array}$ & $\begin{array}{c}\text { V. pusillus } \\
\text { arizonae }\end{array}$ & SDSU & 2889 & USA: AZ, La Paz Co., Cibola NWR & 33.36583 & -114.6786 & 7 & $\mathrm{~J}$ \\
\hline $\begin{array}{l}\text { V. bellii } \\
\text { arizonae }\end{array}$ & $\begin{array}{c}\text { V. pusillus } \\
\text { arizonae }\end{array}$ & SDSU & 2890 & USA: AZ, Mohave Co., Havasu NWR & 34.69024 & -114.4403 & 7 & $\mathrm{~J}$ \\
\hline $\begin{array}{l}\text { V. bellii } \\
\text { arizonae }\end{array}$ & $\begin{array}{l}\text { V. pusillus } \\
\text { arizonae }\end{array}$ & SDSU & 2892 & USA: AZ, Mohave Co., Havasu NWR & 34.69024 & -114.4403 & 1 & $\mathrm{~J}$ \\
\hline $\begin{array}{l}V . \text { bellii } \\
\text { arizonae }\end{array}$ & $\begin{array}{l}\text { V. pusillus } \\
\text { arizonae }\end{array}$ & SDSU & 2893 & USA: AZ, Mohave Co., Havasu NWR & 34.69024 & -114.4403 & 7 & $\mathrm{~J}$ \\
\hline $\begin{array}{l}\text { V. bellii } \\
\text { arizonae }\end{array}$ & $\begin{array}{l}\text { V. pusillus } \\
\text { arizonae }\end{array}$ & SDSU & 2894 & USA: AZ, Mohave Co., Havasu NWR & 34.69024 & -114.4403 & 7 & $\mathrm{~J}$ \\
\hline $\begin{array}{l}\text { V. bellii } \\
\text { arizonae }\end{array}$ & $\begin{array}{c}\text { V. pusillus } \\
\text { arizonae }\end{array}$ & SDSU & 2903 & USA: AZ, Pima Co. & 32.325 & -110.7022 & 11 & $\mathrm{G}$ \\
\hline $\begin{array}{l}\text { V. bellii } \\
\text { arizonae }\end{array}$ & $\begin{array}{l}\text { V. pusillus } \\
\text { arizonae }\end{array}$ & SDSU & 2904 & USA: AZ, Pima Co. & 32.32473 & -110.7038 & 14 & $\mathrm{G}$ \\
\hline $\begin{array}{l}\text { V. bellii } \\
\text { arizonae }\end{array}$ & $\begin{array}{c}\text { V. pusillus } \\
\text { arizonae }\end{array}$ & SDSU & 2905 & USA: AZ, Pima Co. & 32.33775 & -110.6913 & 7 & $\mathrm{G}$ \\
\hline $\begin{array}{l}\text { V. bellii } \\
\text { arizonae }\end{array}$ & $\begin{array}{c}\text { V. pusillus } \\
\text { arizonae }\end{array}$ & SDSU & 2906 & USA: AZ, Pima Co. & 32.29703 & -110.6218 & 7 & $\mathrm{G}$ \\
\hline
\end{tabular}


Table 1 continued

\begin{tabular}{|c|c|c|c|c|c|c|c|c|}
\hline $\begin{array}{l}\text { Current } \\
\text { Taxonomy }\end{array}$ & $\begin{array}{l}\text { Proposed } \\
\text { Taxonomy }\end{array}$ & Museum & Tissue & Locality & Latitude & Longitude & Fig. 3 & Group \\
\hline $\begin{array}{l}\text { V. bellii } \\
\text { arizonae }\end{array}$ & $\begin{array}{l}\text { V. pusillus } \\
\text { arizonae }\end{array}$ & SDSU & 2907 & USA: AZ, Pima Co. & 32.31226 & -110.5628 & 7 & G \\
\hline $\begin{array}{l}\text { V. bellii } \\
\text { arizonae }\end{array}$ & $\begin{array}{l}\text { V. pusillus } \\
\text { arizonae }\end{array}$ & SDSU & 2908 & USA: AZ, Santa Cruz Co. & 31.39533 & -111.0899 & 7 & G \\
\hline $\begin{array}{l}\text { V. bellii } \\
\text { arizonae }\end{array}$ & $\begin{array}{l}\text { V. pusillus } \\
\text { arizonae }\end{array}$ & SDSU & 2909 & USA: AZ, Santa Cruz Co. & 31.39868 & -111.0890 & 8 & G \\
\hline $\begin{array}{l}\text { V. bellii } \\
\text { arizonae }\end{array}$ & $\begin{array}{l}\text { V. pusillus } \\
\text { arizonae }\end{array}$ & SDSU & 2910 & USA: AZ, Santa Cruz Co. & 31.38865 & -111.0934 & 7 & $\mathrm{G}$ \\
\hline $\begin{array}{l}\text { V. bellii } \\
\text { arizonae }\end{array}$ & $\begin{array}{l}\text { V. pusillus } \\
\text { arizonae }\end{array}$ & SDSU & 2911 & USA: AZ, Santa Cruz Co. & 31.52756 & -110.7115 & 7 & G \\
\hline $\begin{array}{l}\text { V. bellii } \\
\text { arizonae }\end{array}$ & $\begin{array}{l}\text { V. pusillus } \\
\text { arizonae }\end{array}$ & SDSU & 2917 & USA: AZ, Graham Co. & 32.56286 & -109.7972 & 7 & G \\
\hline $\begin{array}{l}\text { V. bellii } \\
\text { arizonae }\end{array}$ & $\begin{array}{l}\text { V. pusillus } \\
\text { arizonae }\end{array}$ & SDSU & 2918 & USA: AZ, Graham Co. & 32.5624 & -109.7941 & 7 & G \\
\hline $\begin{array}{l}\text { V. bellii } \\
\text { arizonae }\end{array}$ & $\begin{array}{l}\text { V. pusillus } \\
\text { arizonae }\end{array}$ & SDSU & 2919 & USA: AZ, Graham Co. & 32.56843 & -109.7609 & 6 & G \\
\hline $\begin{array}{l}\text { V. bellii } \\
\text { arizonae }\end{array}$ & $\begin{array}{l}\text { V. pusillus } \\
\text { arizonae }\end{array}$ & SDSU & 2920 & USA: AZ, Graham Co. & 32.67881 & -109.7741 & 7 & G \\
\hline $\begin{array}{l}\text { V. bellii } \\
\text { arizonae }\end{array}$ & $\begin{array}{l}\text { V. pusillus } \\
\text { arizonae }\end{array}$ & UCLA & 05 N7314 & USA: AZ, La Paz Co. & 33.36583 & -114.6786 & 9 & $\mathrm{~J}$ \\
\hline $\begin{array}{l}\text { V. bellii } \\
\text { arizonae }\end{array}$ & $\begin{array}{l}\text { V. pusillus } \\
\text { arizonae }\end{array}$ & UCLA & $09 \mathrm{~N} 15950$ & USA: AZ, Cochise Co. & 31.59055 & -109.5088 & 14 & G \\
\hline $\begin{array}{l}\text { V. bellii } \\
\text { arizonae }\end{array}$ & $\begin{array}{l}\text { V. pusillus } \\
\text { arizonae }\end{array}$ & UWBM & 82503 & MX: Municipo el Fuerte & 26.275 & -108.795 & 12 & $\mathrm{~F}$ \\
\hline $\begin{array}{l}\text { V. bellii } \\
\text { arizonae }\end{array}$ & $\begin{array}{l}\text { V. pusillus } \\
\text { arizonae }\end{array}$ & UWBM & 82612 & MX: Municipo el Fuerte & 26.275 & -108.795 & 7 & $\mathrm{~F}$ \\
\hline $\begin{array}{l}\text { V. bellii } \\
\text { pusillus }\end{array}$ & $\begin{array}{l}\text { V. pusillus } \\
\text { pusillus }\end{array}$ & LSU & 3912 & USA: CA, San Bernardino Co. & 35.71288 & -116.0532 & 7 & $\mathrm{H}$ \\
\hline $\begin{array}{l}\text { V. bellii } \\
\text { pusillus }\end{array}$ & $\begin{array}{l}\text { V. pusillus } \\
\text { pusillus }\end{array}$ & SDNHM & 51813 & USA: CA, San Diego Co., Bonita & 32.66336 & -117.0421 & 14 & I \\
\hline $\begin{array}{l}\text { V. bellii } \\
\text { pusillus }\end{array}$ & $\begin{array}{l}\text { V. pusillus } \\
\text { pusillus }\end{array}$ & SDSU & 2866 & USA: CA, San Diego Co., Oceanside & 33.24586 & -117.2841 & 2 & I \\
\hline $\begin{array}{l}\text { V. bellii } \\
\text { pusillus }\end{array}$ & $\begin{array}{l}\text { V. pusillus } \\
\text { pusillus }\end{array}$ & SDSU & 2877 & $\begin{array}{l}\text { USA: CA, San Diego Co., Camp } \\
\text { Pendelton }\end{array}$ & 33.26878 & -117.3784 & 3 & I \\
\hline $\begin{array}{l}\text { V. bellii } \\
\text { pusillus }\end{array}$ & $\begin{array}{l}\text { V. pusillus } \\
\text { pusillus }\end{array}$ & SDSU & 2878 & $\begin{array}{l}\text { USA: CA, San Diego Co., San Diego } \\
\text { River }\end{array}$ & 33.23898 & -117.3127 & 2 & I \\
\hline $\begin{array}{l}\text { V. bellii } \\
\text { pusillus }\end{array}$ & $\begin{array}{l}\text { V. pusillus } \\
\text { pusillus }\end{array}$ & SDSU & 2879 & $\begin{array}{l}\text { USA: CA, San Diego Co., San Diego } \\
\text { River }\end{array}$ & 33.23898 & -117.3127 & 3 & I \\
\hline $\begin{array}{l}\text { V. bellii } \\
\text { pusillus }\end{array}$ & $\begin{array}{l}\text { V. pusillus } \\
\text { pusillus }\end{array}$ & SDSU & 2880 & $\begin{array}{l}\text { USA: CA, San Diego Co., San Diego } \\
\text { River }\end{array}$ & 33.2399 & -117.3068 & 7 & I \\
\hline $\begin{array}{l}\text { V. bellii } \\
\text { pusillus }\end{array}$ & $\begin{array}{l}\text { V. pusillus } \\
\text { pusillus }\end{array}$ & SDSU & 2867 & $\begin{array}{l}\text { USA: CA, San Diego Co., San Diego } \\
\text { River }\end{array}$ & 32.83974 & -117.007 & 10 & I \\
\hline $\begin{array}{l}\text { V. bellii } \\
\text { pusillus }\end{array}$ & $\begin{array}{l}\text { V. pusillus } \\
\text { pusillus }\end{array}$ & SDSU & 2868 & $\begin{array}{l}\text { USA: CA, San Diego Co., San Diego } \\
\text { River }\end{array}$ & 32.83974 & -117.007 & 3 & I \\
\hline $\begin{array}{l}\text { V. bellii } \\
\text { pusillus }\end{array}$ & $\begin{array}{l}\text { V. pusillus } \\
\text { pusillus }\end{array}$ & SDSU & 2869 & $\begin{array}{l}\text { USA: CA, San Diego Co., San Diego } \\
\text { River }\end{array}$ & 32.83974 & -117.007 & 3 & I \\
\hline $\begin{array}{l}\text { V. bellii } \\
\text { pusillus }\end{array}$ & $\begin{array}{l}\text { V. pusillus } \\
\text { pusillus }\end{array}$ & SDSU & 2870 & $\begin{array}{l}\text { USA: CA, San Diego Co., San Diego } \\
\text { River }\end{array}$ & 32.83974 & -117.007 & 5 & I \\
\hline $\begin{array}{l}\text { V. bellii } \\
\text { pusillus }\end{array}$ & $\begin{array}{l}\text { V. pusillus } \\
\text { pusillus }\end{array}$ & SDSU & 2872 & $\begin{array}{l}\text { USA: CA, San Diego Co., Santa } \\
\text { Margarita River }\end{array}$ & 33.23838 & -117.3858 & 3 & I \\
\hline $\begin{array}{l}\text { V. bellii } \\
\text { pusillus }\end{array}$ & $\begin{array}{l}\text { V. pusillus } \\
\text { pusillus }\end{array}$ & SDSU & 2873 & $\begin{array}{l}\text { USA: CA, San Diego Co., Santa } \\
\text { Margarita River }\end{array}$ & 33.23838 & -117.3858 & 3 & I \\
\hline
\end{tabular}


Table 1 continued

\begin{tabular}{|c|c|c|c|c|c|c|c|c|}
\hline $\begin{array}{l}\text { Current } \\
\text { Taxonomy }\end{array}$ & $\begin{array}{l}\text { Proposed } \\
\text { Taxonomy }\end{array}$ & Museum & Tissue & Locality & Latitude & Longitude & Fig. 3 & Group \\
\hline $\begin{array}{l}V . \text { bellii } \\
\text { pusillus }\end{array}$ & $\begin{array}{l}\text { V. pusillus } \\
\text { pusillus }\end{array}$ & SDSU & 2895 & $\begin{array}{l}\text { USA: CA, San Diego Co., San Diego } \\
\text { River }\end{array}$ & 32.83974 & -117.007 & 13 & I \\
\hline
\end{tabular}

Locality and voucher information for 86 individual samples from across the breeding distribution for Bell's Vireo. Current and proposed taxonomy are indicated. Specimen identifications on the ND2 phylogeny are listed in column labeled Fig. 3. Group refers to population groupings shown in Fig. 1

ANSP The Academy of Natural Sciences of Drexel University, LSU Louisiana State University Museum of Natural Science, $K U$ University of Kansas Natural History Museum, MBM Marjorie Barrick Museum, University of Nevada, Las Vegas, MVZ Museum of Vertebrate Zoology at Berkeley, SDNHM San Diego Natural History Museum, SDSU San Diego State University Museum of Biodiversity, UCLA University of California, Los Angeles, Conservation Genetics Resource Center, UWBM University of Washington Burke Museum, Co. County, NWR National Wildlife Refuge

${ }^{a}$ Individual now held at University of Washington Burke Museum

classification. Such a reassessment is desirable in order to ensure that resources to provide biological and legal protection to Bell's Vireo are used as effectively as possible and in a manner consistent with the best available scientific information. Therefore, we undertook a genetic study to characterize the Bell's Vireo complex and describe evolutionary relationships within the group. Our goal was to infer broad scale phylogeographic patterns in the Bell's Vireo complex using genetic markers from across the genome. We compared these data to past and present niche models for the species to provide further ecological and historical insight into observed genetic patterns. These results will inform conservation decisions for the entire complex and in particular, help evaluate the taxonomic distinctiveness of the endangered Least Bell's Vireo.

\section{Methods}

Bell's Vireo tissue samples were obtained for 86 individuals from throughout the breeding distribution (Table 1; Fig. 1). Total genomic DNA was extracted with Qiagen DNeasy extraction kits following the manufacturer's protocol. We amplified 1041 base pairs of the mtDNA gene NADH dehydrogenase subunit 2 (ND2) using primers L-met 5215 and H-6316 and internal primers H-5766 and L-5758 (Cadena et al. 2007; Hackett 1996). Amplifications were completed in $28 \mu \mathrm{L}$ reactions with the following conditions: denaturation at $95{ }^{\circ} \mathrm{C}$ for $15 \mathrm{~min}$, followed by: 4 cycles of $95{ }^{\circ} \mathrm{C}$ for $30 \mathrm{~s}, 58^{\circ} \mathrm{C}$ for $30 \mathrm{~s}, 72{ }^{\circ} \mathrm{C}$ for $60 \mathrm{~s}, 4$ cycles of $95{ }^{\circ} \mathrm{C}$ for $30 \mathrm{~s}, 56{ }^{\circ} \mathrm{C}$ for $30 \mathrm{~s}, 72{ }^{\circ} \mathrm{C}$ for $60 \mathrm{~s}, 4$ cycles of $95{ }^{\circ} \mathrm{C}$ for $30 \mathrm{~s}, 54{ }^{\circ} \mathrm{C}$ for $30 \mathrm{~s}, 72^{\circ} \mathrm{C}$ for $60 \mathrm{~s}, 19$ cycles of $95{ }^{\circ} \mathrm{C}$ for $30 \mathrm{~s}, 52{ }^{\circ} \mathrm{C}$ for $30 \mathrm{~s}, 72{ }^{\circ} \mathrm{C}$ for $60 \mathrm{~s}$. A 7 -minute extension at $72{ }^{\circ} \mathrm{C}$ followed the cycling, completed with a $4{ }^{\circ} \mathrm{C}$ soak. The PCR products were purified using ExoSap before being submitted to Macrogen, Inc (Rockville, MD) for sequencing. Following sequencing, the data were imported into Sequencher, vers. 5.0 (Gene Codes Corporation), and complementary strands were aligned and read for each individual (GenBank Accession numbers KM262667-KM262751).

In addition to ND2 sequences, we also obtained single nucleotide polymorphism (SNP) data for 48 individuals using the genotyping-by-sequencing (GBS) approach implemented by the Cornell Institute of Genomic Diversity. GBS is a technique for construction of reduced representation libraries for the discovery of SNPs from throughout the genome using Illumina sequencing (Elshire et al. 2011). Following the Elshire et al. (2011) protocol, DNA from each individual (at concentrations between 10 and $100 \mathrm{ng} / \mu \mathrm{L}$ ) was digested with a restriction enzyme (PstI). After the restriction digest, two barcodes (a sample specific and a common adapter) were added that bind to the enzyme's cut sites. Samples were then pooled, cleaned, and amplified with PCR to increase fragment concentration. Samples were then run on a partial lane (48 of 96 samples) of a $100 \mathrm{bp}$ single-end Illumina Hiseq 2000. Following sequencing, SNP discovery and genotyping were performed using a network based analysis pipeline, UNEAK (Universal Network Enabling Analysis Kit), a protocol developed for species without a reference genome ( $\mathrm{Lu}$ et al. 2013). The UNEAK pipeline is designed to overcome complexities that impede SNP discovery, such as repeats, paralogs, and sequencing errors. Briefly, sequence reads were trimmed to $64 \mathrm{bp}$, and then all identical reads were pooled to form distinct tags. Pairwise comparisons were then performed between all distinct tags to identify tag pairs differing at a single bp position. Tag pair networks were created connecting a series of tags differing by only a SNP, similar to a haplotype network. Finally, only reciprocal tag pairs are identified as SNPs for further analysis (Lu et al. 2013). After completion of the UNEAK pipeline, custom perl scripts written by T. A. White (White et al. 2013) were used to remove reverse complements (Lynch 2009). 
a

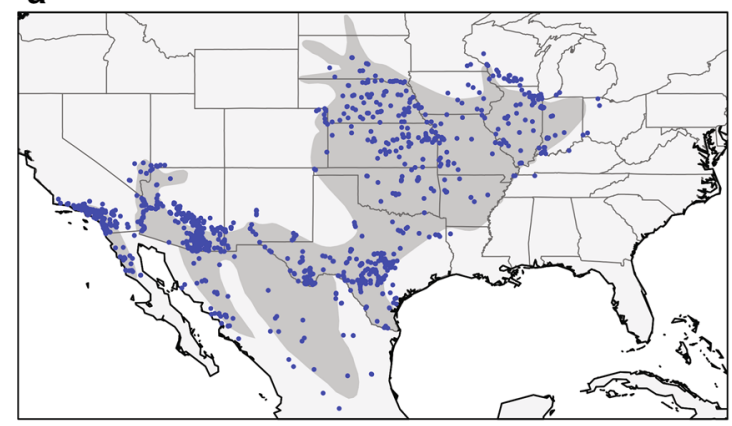

c

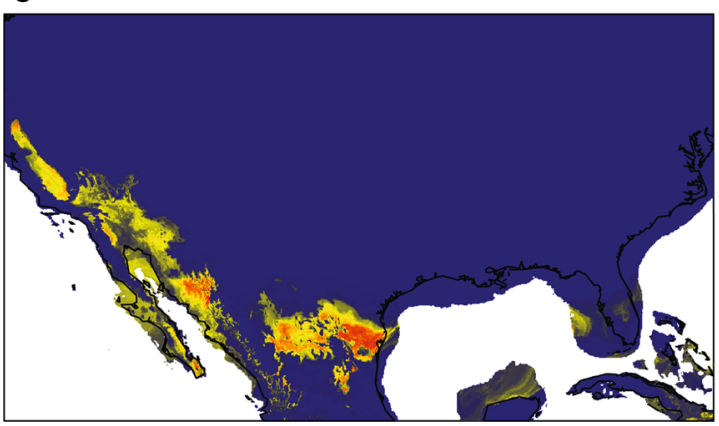

Fig. 2 Ecological niche models of Bell's Vireo a Bell's Vireo records used to create the niche model. b Current ecological niche models for Vireo bellii. The color represents habitat suitability, with warmer colors indicating greater probability of occurrence. c CCSM

\section{Phylogenetic analyses}

ND2 sequences were analyzed using maximum likelihood (RAxML, Stamatakis et al. 2008) and Bayesian (BEAST v1.6.2, Drummond and Rambaut 2007) approaches. Phylogenies were rooted with close relatives of Bell's Vireo, Vireo osburni (GenBank, KM115380) and Vireo modestus (GenBank, KM115353) (Slager et al. 2014). The best-fit model of evolution for the separate ND2 codon positions was determined with jModelTest (Posada 2008) using Bayesian Information Criterion. A BEAST input file was then created in BEAUti v1.6.2 (Drummond and Rambaut 2007) with a Markov chain Monte Carlo (MCMC) of $100,000,000$ generations sampling every 10,000 generations. An HKY model of evolution was determined to be the most appropriate model for all codon positions according to jModelTest v2.1.6 (Darriba et al. 2012; Guindon and Gascuel 2003). A preliminary analysis determined that the data were sufficiently clocklike and therefore the analysis was run with a strict molecular clock and a standard substitution rate of 0.0115 (2.3\% divergence $\mathrm{my}^{-1}$ ) (Klicka et al. 2011). Analyses were completed in duplicate and examined in Tracer v1.5 to ensure model parameters had converged. TREEANNOTATOR v1.5.4 (Drummond and Rambaut 2007) was used to generate a maximum clade credibility tree with a burn-in of

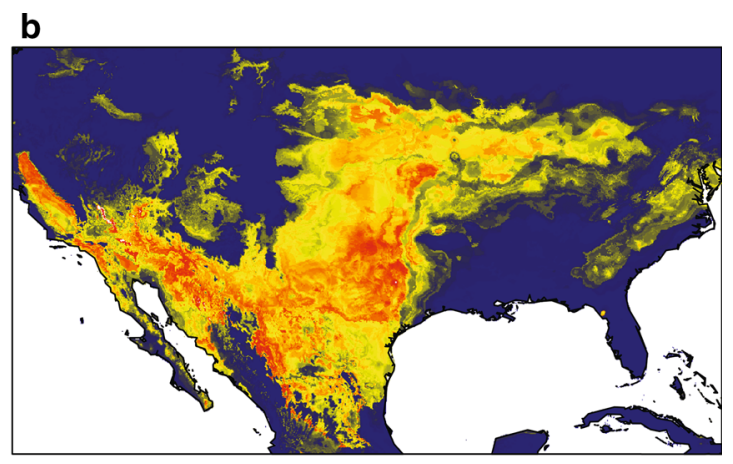

d

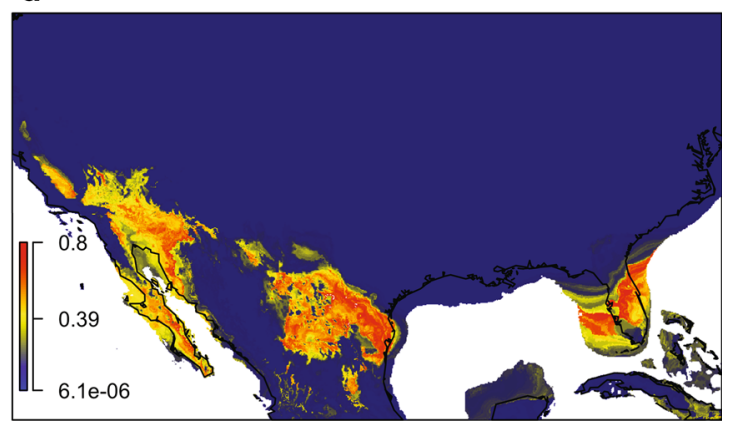

and $\mathbf{d}$ MIROC are historical ecological niche models of last glacial maximum (21,000 years B.P.) for Vireo bellii. All figures have been plotted to the same color scale, shown in $\mathbf{d}$

1000 samples that could then be visualized with FIGTREE v1.3.1. RAxML was used to construct a ML tree with a $\mathrm{GTR}+\mathrm{G}$ model of sequence evolution imposed for the separate codons and nodal support was assessed via bootstrapping, and the best tree was visualized with FIGTREE v1.3.1. In addition, haplotype networks, using all 86 sequenced ingroup individuals, were constructed to reveal phylogeographic patterns and relationships among individuals and populations with the program NETWORK, version 4.516 (Bandelt et al. 1999). For the SNP dataset, loci were identified from across the genome, but because no reference genome was available for mapping potentially linked loci, SNPs could not be phased. Therefore, the SNPs for each individual were concatenated and collapsed into a consensus sequence with heterozygous positions receiving ambiguity codes. Furthermore, because only variable information (SNPs) was used for the ML analyses, a correction for ascertainment bias was required. However, in some cases SNPs were not considered variable by RAxML v8.0 (Stamatakis 2014). For example, if a particular SNP for 5 individuals was $\mathrm{A}, \mathrm{A}, \mathrm{A}, \mathrm{M}$, and $\mathrm{R}$, then all individuals would be considered identical because " $M$ " and "R" could both potentially be "A". As required by RAxML v8.0, "invariable" sites like these were removed prior to analysis (Stamatakis 2014). Once these sites were trimmed and only sites with less than $20 \%$ missing data 
were retained, a filtered dataset of 3241 SNPs remained. Following filtering for RAxML analysis, an unrooted ML analysis was constructed with an ascertainment bias correction, 10,000 rapid bootstraps, and a GTR $+\mathrm{G}$ model of evolution. Furthermore, parsimony analyses were performed in PAUP* 4.0 (Swofford 2003) with the full SNP dataset (4679 SNPs) with a heuristic search, random sequence addition, and 1000 bootstraps to evaluate support.

\section{Population analyses}

Population-level analyses were performed with 1) a dataset of 4679 informative SNPs for 45 individuals that permitted $20 \%$ missing data per locus, and 2) ND2 data of 85 of the 86 individuals sequenced for ND2. The SNP dataset differs in size between the population-level analyses and the phylogenetic analyses because it includes heterozygotous loci removed as a result of the ascertainment bias correction. For the ND2 dataset, analyses were completed with and without one male individual (MBM 13821), but only those results excluding MBM 13821 are reported. This specimen likely represents $V$. $b$. arizonae (see results), but retains the mtDNA of an eastern form. The inclusion of MBM 13821 inflated nucleotide diversity scores for western birds, but did not alter significance of other tests.

Individual based population assignment tests were completed with STRUCTURE v2.3.4 (Pritchard et al. 2000). STRUCTURE assigns individuals to a predetermined number of populations $(\mathrm{K})$ probabilistically and can be used to examine the amount of admixture within each individual. $\operatorname{Pr}(\mathrm{X} \mid \mathrm{K})$ was calculated for values of $\mathrm{K}$ between 1-6 to determine the most likely number of distinct clusters within Bell's Vireo. Furthermore, the optimal K was examined via $\Delta K$ (Evanno et al. 2005), implemented in STRUCTURE HARVESTER (Earl 2012). STRUCTURE analyses were run in duplicate for 500,000 generations with a burnin of 5000 generations using both correlated allele frequencies and permitting admixture.

To investigate the presence of population structure, an analysis of molecular variance (AMOVA) was used to calculate $\Phi$-statistics and to quantify the percent variation among and within populations for both the mtDNA and GBS datasets. Sampling for this project had to be conducted opportunistically; therefore, some populations lack

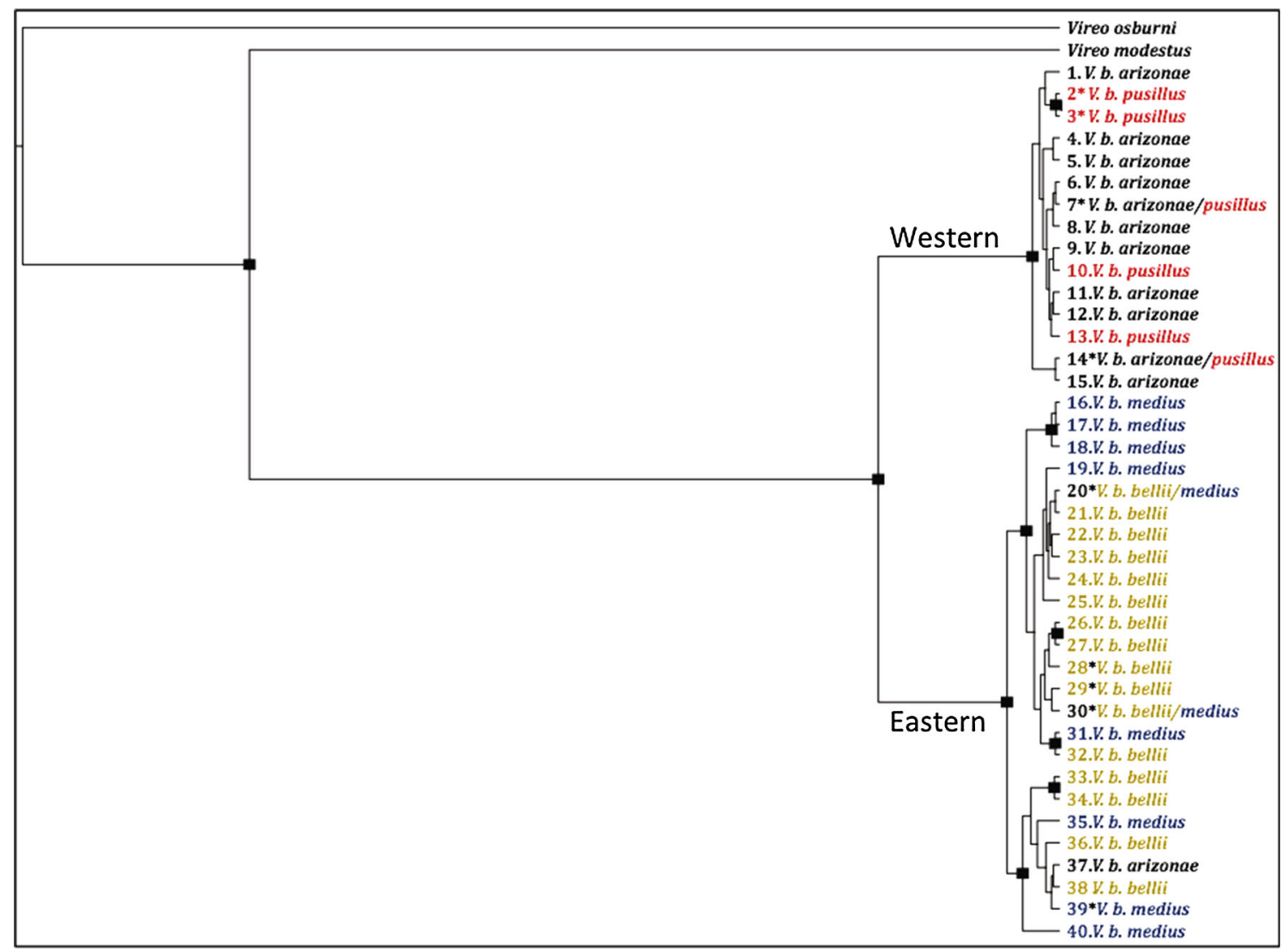

Fig. 3 The ND2 maximum clade credibility tree rooted by the outgroup method. Samples are labeled by their currently recognized taxonomy and terminals representing multiple individuals are indicated with an asterisk. Nodes that received posterior probability of 0.95 or higher are indicated with a black square 
the desired number of individuals to perform detailed population level analyses. Thus, we pooled geographically proximate individuals to increase sample sizes (Fig. 1). In addition, individuals were pooled according to subspecies distinction, only to test whether subspecies capture genetic structure. In addition to AMOVA, population structure was further examined by calculating pairwise $F_{\text {st }}$ values. The AMOVA and pairwise $\mathrm{F}_{\mathrm{st}}$ calculations were completed in ARELQUIN (Excoffier et al. 2005). Some avian species that co-occur with the Bell's Vireo are isolated into western and eastern clades by the Sierra Madre Occidental (SMO) (Zink et al. 2001); therefore, we performed a partial Mantel test to address the possibility of the SMO acting as a barrier to gene flow in the Bell's Vireo complex. The Isolation by Distance Web Service (Jensen et al. 2005) was used to calculate the partial Mantel test for a correlation between genetic distance and whether populations were on the same or different sides of the SMO, while controlling for geographic distance. Genetic distance was measured with Slatkin's M and Euclidean distance between populations yielded the geographic distance matrix. For this analysis, samples were pooled based on geographic proximity into sampling populations, resulting in nine populations (Fig. 1A-I).

\section{Niche modeling}

We constructed climatic niche models using occurrence data from 29 natural history collections as well as eBird, an observational repository. These records were acquired through the ORNIS2 (www.ornisnet.org) and Vertnet (www.vertnet.org) online data access portals. A total of 7290 unfiltered occurrence data points were collected, $83 \%$ from eBird. Data points were then removed if they fell outside of the breeding distribution (BirdLife International and NatureServe 2013) by greater than 1 degree, and additional records were removed for identical coordinates and records with coordinates lacking environmental data. Following filtering, 1709 records remained and these were used for niche modeling (Fig. 2a). We used 19 bioclimatic variables from worldclim (Hijmans et al. 2005) and four non-climate variables: elevation, slope, aspect and terrain roughness for a total of 23 variables to generate the model, all at a resolution of 2.5 arc-minutes $(\sim 4 \times 4 \mathrm{~km}$ grid cell). An initial niche model was produced in Maxent (version $3.3 .3 \mathrm{k}$ ) with default settings, using all 23 variables, with the training region defined as North and Central America. In order to prevent model over fitting, only variables contributing more than $5 \%$ to the generation of the model were retained for the rest of the analyses (Brown and Knowles 2012) and those were: mean annual temperature (bio1), mean temperature of the warmest quarter (bio10), mean annual precipitation (bio12), and precipitation of the wettest quarter (bio16). The beta multiplier parameter controls the complexity of the niche model, and using an AICc model selection approach (Warren and Seifert 2011), we tested beta multiplier values from 0 to 15 and found 0 to be the best fit. The current climatic niche model was validated using $\mathrm{k}$-fold partitioning. Here, the occurrence dataset is broken up into 5 pieces (20\% of the occurrences in each). Four pieces are the training data, the remaining portion is the testing data. The training sets are used to construct niche models, and their ability to correctly predict occurrence is tested on the test dataset. We did this 5 times, each time changing which subset of the dataset that was assigned as the testing set. We took the average of the AUC (area under the curve), which is a measure of niche modeling performance, where 0.5 means the model does no better than random (it ranges from 0 to 1). In order to place the demographic history of Bell's Vireo in a historical and spatial context, the current niche model was then projected onto climate data for the Last Glacial Maximum ( $\mathrm{LGM} \approx 21,000 \mathrm{BP}$ ) for two models: CCSM (Collins et al. 2006) and MIROC (Hasumi and Emori 2004). It has been demonstrated that projection of niche models into climate space outside of the range of the data with which the models were built can lead to unrealistic extrapolation (Owens et al. 2013), however we have found our results to be robust to such problems. All niche modeling was executed in $\mathrm{R}$, using Maxent through the dismo (Hijmans et al. 2005), maptools (Bivand and Lewin-Koh 2015), rgeos (Bivand and Rundel 2014) and raster packages (Hijmans 2015).

\section{Results}

\section{Phylogenetic analyses}

Analysis of 86 individuals for the complete ND2 gene revealed 40 unique haplotypes with 73 variable and 44 phylogenetically informative sites. The ML and Bayesian topologies were largely congruent with no strongly supported nodes in conflict (Fig. 3, Bayesian tree shown). Both analyses recovered two major clades that are approximately $3 \%$ divergent from one another. Using a standard rate of mtDNA sequence divergence of 0.0115 per million years (Klicka et al. 2011), the BEAST analysis estimated the clades diverged between 1.11 and 2.04 mya (95\% HPD). The two clades are geographically cohesive, with one clade found in the eastern part of the distribution and the other clade found in the western part of the distribution (Fig. 3). The western clade is primarily comprised of individuals from California, Arizona, and Mexico (groups F-J on Fig. 1), while the eastern clade is composed of individuals from Missouri, Oklahoma, and Texas 


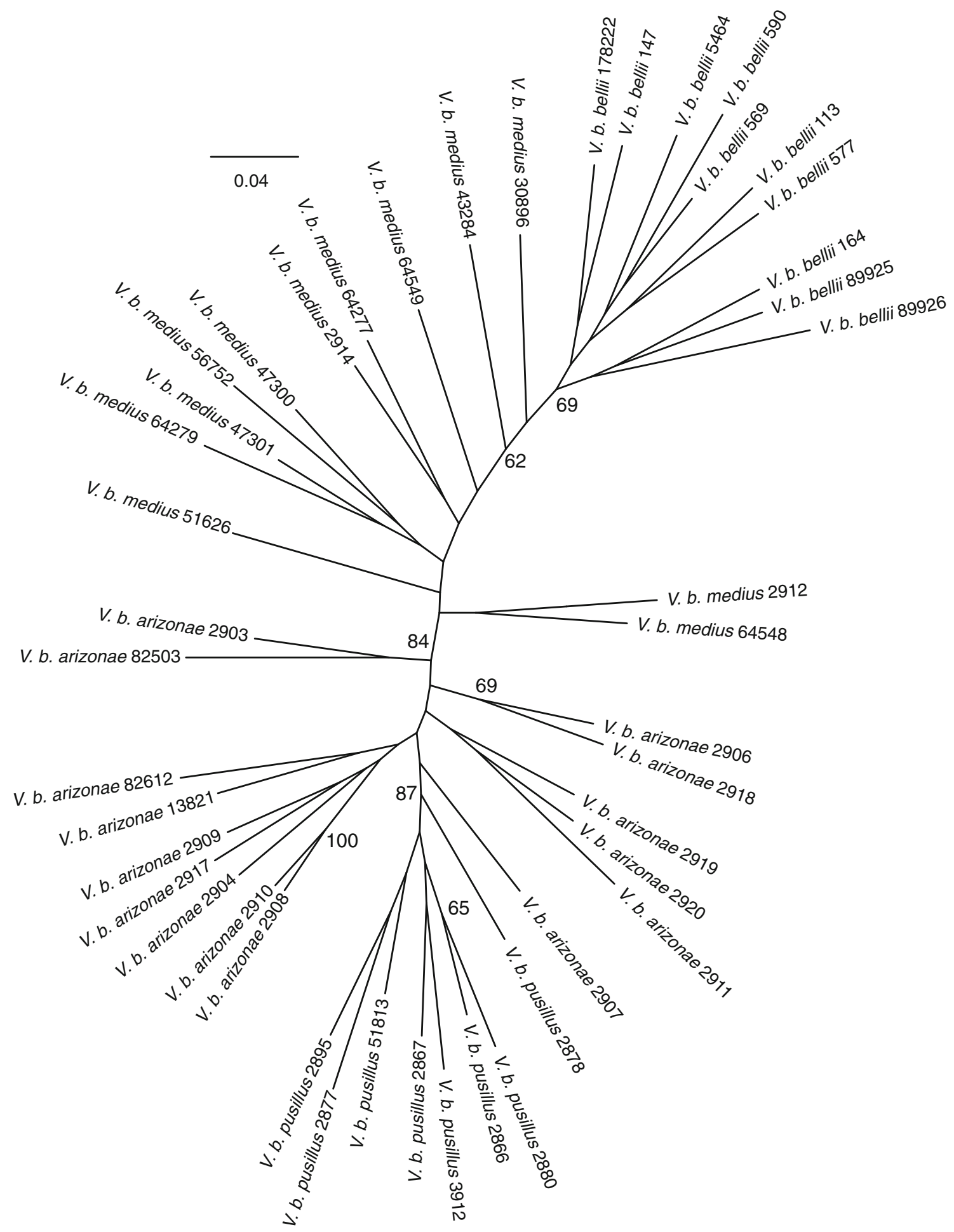

Fig. 4 Maximum likelihood of SNP data. Node support was established by rapid bootstrapping and only relationships with BS $>60$ are shown. Numbers correspond to specimen voucher numbers of Table 1

(groups A-E on Fig. 1). Thus, individuals of $V . b$. pusillus and $V . b$. arizonae belong to the western clade, and individuals of $V$. b. bellii and $V$. b. medius belong to the eastern clade. The eastern/western division is upheld by all but one individual used to construct this topology. The single exception was an individual (MBM 13821) collected in April from Clark Co, Nevada, within the breeding range of $V$. b. arizonae. Instead of grouping in the western clade 

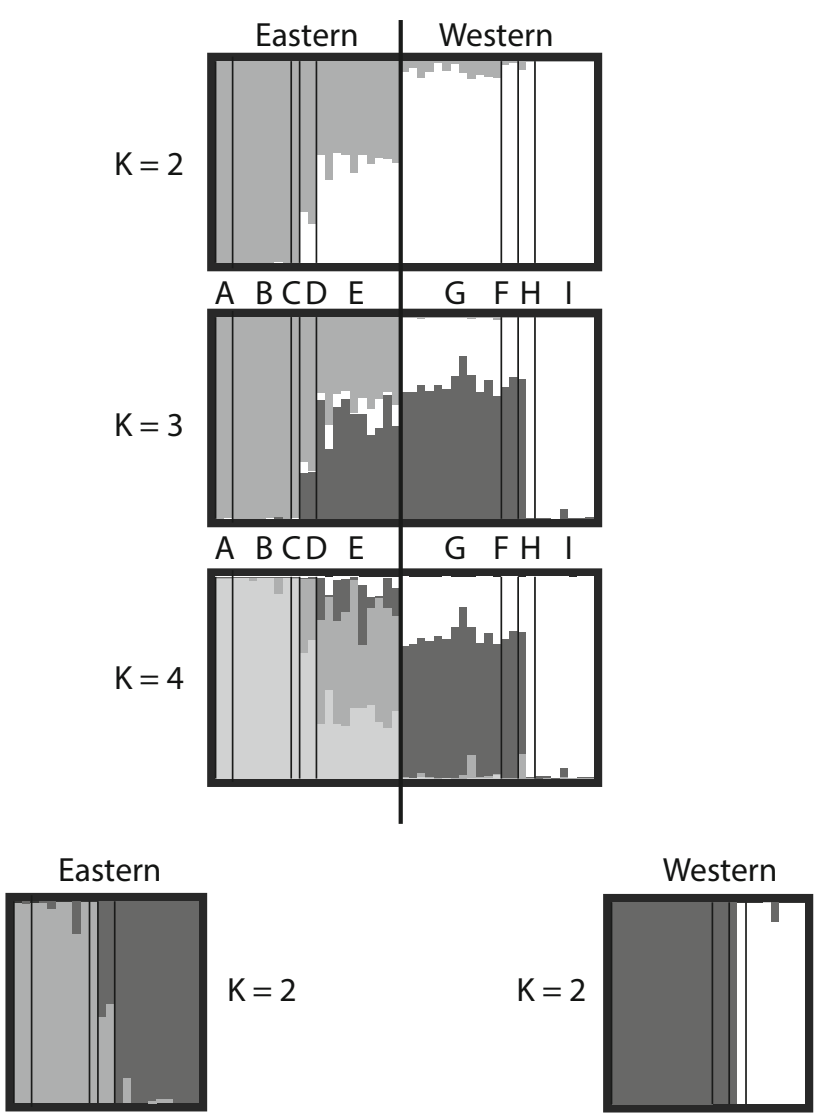

A BCD E
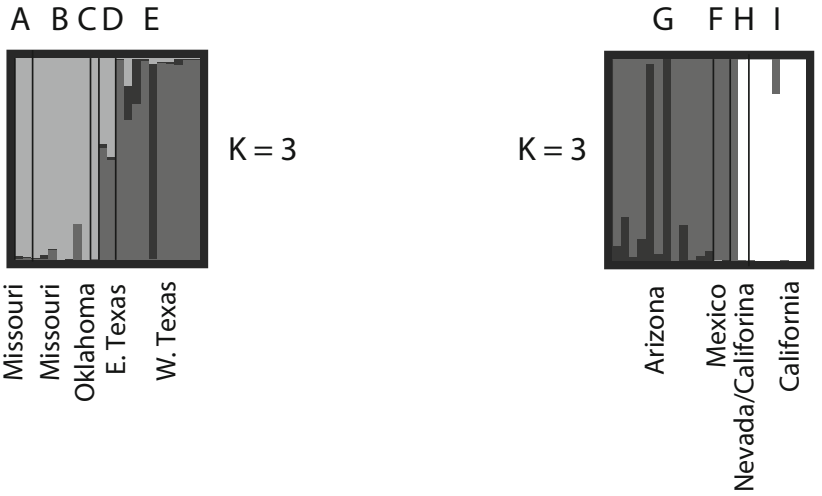

Fig. 5 STRUCTURE analyses with admixture for all individuals $(\mathrm{K}=2-4)$. The bottom left and right panels displays STRUCTURE results for separate analyses of the eastern and western sub-clades $(\mathrm{K}=2,3)$. Columns represent individuals and black lines separate sampling locations as labeled on $A$ Missouri, $B$ Missouri, $C$ Oklahoma, $D$ South Central Texas, $E$ Western Texas, $F$ Mexico, $G$ Eastern Arizona, $H$ West California/Nevada, $I$ Coastal California

with other members of $V . \quad b$. arizonae, this individual groups with the eastern clade. However, an examination of both plumage and morphology (tail length) identify MBM 13821 as a $V$. b. arizonae individual. Most relationships within the western and eastern clades did not receive statistically significant posterior probability support, and none of the subspecies formed monophyletic groups based on their mtDNA (Fig. 3).
The haplotype network (Fig. 1) showed structure similar to that observed in the ML and Bayesian topologies. The eastern and western clades were identified, with 27 mutational steps separating the most genetically similar eastern and western individuals. Within the eastern clade, 25 unique haplotypes (out of 42 individuals) were identified, while only 15 (out of 44 individuals) were recovered in the west. The most common haplotype occurred in the western clade and was shared by 21 individuals. This haplotype occurred in individuals from California, Mexico, Nevada and Arizona. The second most common haplotype is composed of 8 individuals found in the eastern clade and includes Texas and Missouri individuals.

Following processing with the UNEAK pipeline, the 48 individuals used for GBS produced a dataset of 24,426 biallelic SNPs. Three individuals were subsequently removed because of missing data for most loci. ML analysis was performed for a dataset that permitted $20 \%$ missing data per locus (3241 SNPs). The SNP ML phylogeny (Fig. 4) separated all individuals into eastern and western clades and this received high bootstrap support (BS $=84 \%)$. The one individual that violated the east/ west trend in the mtDNA dataset (MBM 13821) was recovered in the expected (western) clade in the SNP tree. Within the western clade, the main internal clade that received strong support $(\mathrm{BS}=87 \%)$ united all eight of the endangered $V . b$. pusillus individuals into a clade. The other internal clade with elevated support $(\mathrm{BS}=69 \%)$ is located within the eastern clade and united all of the Vireo bellii bellii individuals. Parsimony analysis identified the same relationships as the ML analysis. Specifically, the east-west split was recovered ( $71 \%$ bootstrap support), Vireo bellii belliii was identified as a clade, and, most importantly, we found support for the endangered $V$. $b$. pusillus (72\% bootstrap).

\section{Population analyses}

The probability of individual STRUCTURE analyses ( $P$ $(\mathrm{XID})$ ) from $\mathrm{K}=1$ to $\mathrm{K}=6$ indicates that $\mathrm{K}=2$ is the most supported value; however, the four-population $(\mathrm{K}=4)$ model received the second best $\Delta \mathrm{K}$ score. Furthermore, $\mathrm{K}=2,3,4$ all received qualitatively similar probability scores: $-145,513.0,-144,494.9,-144,334.2$, respectively. In all population models, Texas individuals (groups D and E; Fig. 5) were an admixture of at least two genetic clusters, while Missouri and Oklahoma birds (groups A-C; Fig. 5) were characterized by one genetic background at all $\mathrm{K}$ values. California birds (groups I and H; Fig. 5) were clustered with specimens from Arizona, Mexico and Nevada for $K=2$, but this genetic background was only partially shared at $\mathrm{K}$ values of 3 and 4 . Thus, at these higher values of $\mathrm{K}$, groups $\mathrm{F}$ and $\mathrm{G}$ show 
Table 2 Pairwise $\mathrm{F}_{\mathrm{st}}$ values for the four different subspecies of the Bell's Vireo complex. $F_{\text {st }}$ results for mtDNA are listed first, followed by SNP results

\begin{tabular}{lllll}
\hline Population & V. b. bellii & V. b. medius & V. b. arizonae & V. b. pusillus \\
\hline V. b. bellii (Eastern) & - & & & \\
V. b. medius (Eastern) & $0.174^{*}, 0.059^{* *}$ & - & & \\
V. b. arizonae (Western) & $0.928^{* *}, 0.135^{* *}$ & $0.924^{* *}, 0.044^{* *}$ & - & \\
V. b. pusillus (Western) & $0.903^{* *}, 0.197^{* *}$ & $0.889^{* *}, 0.091^{* *}$ & $0.324^{* *}, 0.047^{* *}$ & - \\
\hline
\end{tabular}

$* \mathrm{p}=0.00098$

$* * \mathrm{p}<0.00001$

genetic differences not shared with Least Bell's Vireo populations. STRUCTURE can have trouble parsing out individuals into populations if the population structure is hierarchical; therefore, one approach often taken in the literature (Farrington et al. 2014; Hart et al. 2014; Manthey et al. 2011) is to perform separate analyses on different geographic regions. Thus, we further analyzed population structure by completing analyses for the eastern and western sub-clades with $K=1-4$, and we found $K=2$ and $\mathrm{K}=3$ received the best likelihood scores (Fig. 5). Least Bell's Vireo individuals form an almost exclusive cluster for both $\mathrm{K}$ values, while $V$. b. medius individuals from eastern Texas (group D; Fig. 5) continue to be characterized by multiple genetic backgrounds.

$\mathrm{F}_{\text {st }}$ statistics for both the mtDNA and GBS data sets indicated that most of the significant $\mathrm{F}_{\mathrm{st}}$ values were comparisons between eastern and western populations, and all significant $F_{s t}$ values represent comparisons between existing subspecies. Within the western populations, both ND2 and GBS data recovered significant $\mathrm{F}_{\mathrm{st}}$ results for the comparisons of population I (representing $V . b$. pusillus) to populations $\mathrm{G}$ (representing $V$. b. arizonae), and ND2 additionally recovered significant a $F_{\text {st }}$ value for the comparison between populations I and $\mathbf{J}$ (population $\mathbf{J}$ was not represented in GBS dataset) (Online Resource 1). Pooling individuals according to subspecies provided significant $F_{\text {st }}$ results for all comparisons (Table 2). AMOVA analyses for mtDNA (Online Resource 2, 3) indicated geographic structure between the eastern and western clades with $89-90 \%$ of the molecular variation partitioned between the clades. Conversely, AMOVAs for the SNP dataset indicated only $5.5-6.5 \%$ of the variation was explained by east/west clade membership. Pooling samples based on populations (Online Resource 2) versus subspecies distinctions (Online Resource 3) essentially yielded the same results. Quantifying nucleotide diversity $(\pi)$ for the mtDNA dataset indicated less genetic diversity in western populations compared to eastern populations (Online Resource 4). The partial Mantel test examining the correlation between genetic distance and the presence of a barrier in New Mexico produced a significant result $(\mathrm{r}=-0.6518, \mathrm{p}=0.0002)$, indicating that a barrier, rather than isolation by distance explains the relationships between eastern and western individuals.

\section{Niche modeling}

Niche modeling performed well when tested for model validation, yielding a mean testing AUC of 0.97, when averaged across the $5 \mathrm{k}$-fold partitions. The current climate niche model for $V$. $b$. bellii largely reflects the known distribution for breeding Bell's Vireos (Fig. 2b). In addition, the Bell's Vireo historically inhabited the Central Valley of California until their recent extirpation in the late 1900s. The niche model correctly predicts this area as good Bell's Vireo habitat, even without any occurrence records in our dataset from the Central Valley. Projecting the Bell's Vireo niche model back to the LGM identified western and eastern refugia (Fig. 2c, d). One refugium was identified in northeast Mexico and a second likely refugium was found in northwest Mexico, with a potential third in the central valley of California. The eastern and western refugia are isolated geographically with the intervening habitat (highlands associated with the Sierra Madre Occidental) characterized as unsuitable for Bell's Vireo populations.

\section{Discussion}

Genomic methods offer a promising tool for conservation genetics and are quickly becoming a common method for obtaining numerous loci for multiple individuals in phylogenetic and phylogeographic studies (Manthey et al. 2015). However, distinguishing the roles of dispersal, vicariance, and gene flow in explaining population structure continues to be a challenge. Here, we included evidence from mitochondrial and genome-wide variation, as well as environmental niche modeling, to elucidate the evolutionary history of Bell's Vireo populations for management purposes. Our data indicate that gene flow is restricted in the Bell's Vireo. However, restricted gene flow, in the form of isolation by distance, does not adequately explain the overall pattern. The mitochondrial data show a clear division of eastern and western birds, and analysis of the GBS dataset with a partial mantel test further established the presence of a barrier to gene flow between these regions. Additionally, the GBS data set identifies genetically cohesive units within the east and west that correspond to geography. 


\section{Species limits}

Mitochondrial data divide the Bell's Vireo complex into two well-supported clades of individuals from the eastern and western portions of their distribution that are approximately $3 \%$ divergent from one another (Fig. 1). For comparison, Johnson and Cicero (2004) summarized data for 39 pairs of North American avian sister species and reported that, on average, mitochondrial DNA sequences of sister species are $1.86 \%$ divergent. More recently, Arbeláez-Cortés et al. (2014), studying $V$. hypochryseus, identified internal sister clades that are approximately $1.5 \%$ divergent for ND2. These studies suggest the degree of genetic structure within the Bell's Vireo complex is large compared to birds in general, including other vireos. Furthermore, the division between eastern and western clades identified by mtDNA is concordant with genome-wide SNP data (Fig. 4), further establishing the evolutionary independence of the two lineages. Finally, ecological niche modeling revealed eastern clade refugia in northeast Mexico and western clade refugia in northwest Mexico with additional hotspots in California. The refugia in Mexico are allopatric, indicating long established and isolated habitat for the separate clades.

The difficulty in defining a concept of species that is universally applicable has long plagued biologists. Nevertheless, applying a variety of widely used species concepts to our data indicate that the Bell's Vireo constitutes two species. Under a Phylogenetic Species Concept (PSC), species are defined as an irreducible, diagnosable group, with a pattern of ancestry and descent (Zink and McKitrick 1995). The eastern and western clades of Bell's Vireo are clearly separate species based on the PSC because they can be diagnosed on the basis of 23 synapomorphies in ND2. Avise and Ball (1990) introduced a genealogical concordance perspective to the species concept debate, emphasizing the importance of multiple gene phylogenies. These ideas were further developed into a genealogical species concept (GSC) by Baum and Shaw (1995) whereby multiple concordant gene trees are indicative of exclusive groups and species status. Strictly speaking, this project did not examine individual SNP phylogenies in addition to the ND2 phylogeny; rather, we performed a concatenated analysis to determine the overall genomic signal within Bell's Vireo. Therefore, the GSC would not technically be applicable. However, the results of the concatenated analyses indicate that most SNPs support the deep eastern/ western division identified for the Bell's Vireo. Thus, concordance between genomic and mitochondrial data observed in our study supports the division of Bell's Vireo into two independently evolving lineages.

The Biological Species Concept (BSC) defines species based on reproductive isolation. Under the BSC, a group of populations is considered a species if they breed or could potentially breed with one another (Mayr 1993). The possible secondary contact between the east and west clades that was identified in the STRUCTURE analysis suggests caution in the recognition of two species under a traditional interpretation of the BSC. However, this pattern may also be the result of longer coalescent time needed for nuclear markers Even if there is some limited gene flow between the two clades, Gill (2014) showed how recent advances in understanding the role of gene flow in bird speciation forces a new approach to applying the BSC. Given that speciation may occur in the context of gene flow, complete reproductive isolation is deemphasized under this approach, and essential reproductive isolation (lack of free interbreeding) becomes a more appropriate criterion to apply in situations that involve potential gene flow (Gill 2014). Applying this perspective, the two clades qualify for separate species status under the BSC as well.

While the genetic data provide a solid basis for species delimitation regardless of species concept applied, additional lines of evidence identify distinct eastern and western populations. The eastern and western clades are considered field identifiable by their plumage characters (Sibley 2014). Additionally, tail length can differentiate eastern and western populations; western individuals range from 47 to $54 \mathrm{~mm}$ while eastern individuals vary from 41 to $47 \mathrm{~mm}$ (Ridgway 1904). Behavioral divergence has also been observed for populations of Bell's Vireo. Western Bell's Vireos wag their tails side-to-side, similar to a gnatcatcher, but eastern Bell's Vireos flick their tails up and down like a Palm Warbler (Dendroica palmarum) (Greaves and Chadwick 2006; Sibley 2014).

A new species taxonomy is warranted for the Bell's Vireo, based on reciprocally monophyletic sister populations, essential reproductive isolation, and morphological and behavioral evidence. Following rules of taxonomic priority, the name Vireo bellii can be used for eastern populations (Central United States, Texas, Chihuahua Desert), and Vireo pusillus can be used for western populations (Arizona, California, Baja California, Sonoran Desert). For common names, we suggest the use of Bell's Vireo (Vireo bellii) and Least Vireo (Vireo pusillus). The retention of Bell's Vireo and use of Least Vireo returns to the original common names used for each group (Coues 1866, 1890).

\section{Subspecific limits}

The category of subspecies is important for conservation of North American vertebrates under the U.S. Endangered Species Act because subspecies, and even smaller units (i.e., distinct population segments, evolutionarily significant unit) can be recognized as the taxonomic units in need 
of protection independent of the status of the overall species (Haig et al. 2010). For the Bell's Vireo complex, genome-wide SNPs provided additional resolution within the two proposed species (Bell's Vireo and Least Vireo) that can be used to guide subspecies designations. In particular, these data provide insight into the genetic distinctiveness of the endangered Least Bell's Vireo. All eight Least Bell's Vireos formed an exclusive, well-supported cluster in our ML analysis. This group includes individuals sampled from distant parts of the range of the subspecies (San Diego and San Bernardino Counties); thus, monophyly is not the result of a geographically small sample, or sampling only closely related individuals. Our STRUCTURE analysis of a 3 or 4-population model and the subclade analysis of western populations corroborate the ML result for Least Bell's Vireo. Taking this into consideration, the overall signal from the SNP dataset supports maintaining the Least Bell's Vireo as a distinct evolutionary unit that qualifies as a subspecies, evolutionarily significant unit, and distinct population segment. In addition, all individuals of $V . b$. bellii form a clade, with $62 \%$ bootstrap support. Two individuals of $V . b$. medius from south Texas (LSU B43284, LSU B30896) received marginal support as grouping with $V$. b. bellii individuals rather than $V$. b. medius. Nevertheless, none of the four currently recognized subspecies (including $V$. b. medius) are polyphyletic with respect to each other, and thus the tree structure does not show widespread gene flow among subspecies. Monophyly of Bell's Vireo subspecies was not recovered in our ND2 phylogenies, likely due to the small amount of the genome represented by ND2 relative to our SNP data set. Nevertheless, ND2 still showed significant $\mathrm{F}_{\mathrm{st}}$ values between subspecies. Therefore, given our current data and analyses, we recommend retaining the current subspecies. Thus, under our proposed classification, the Bell's Vireo complex includes two species, the Bell's Vireo (Vireo bellii) that includes two subspecies Vireo $b$. bellii and Vireo b. medius, and the Least Vireo (Vireo pusillus) that includes two subspecies, Vireo p. pusillus and Vireo p. arizonae. The endangered subspecies $V$. p. pusillus can be identified as California Least Vireo and V. p. arizonae can be referred to as the Arizona Least Vireo, as in previous works (Coues 1866, 1890).

\section{Biogeographic history of the Bell's vireo}

Physical barriers may facilitate diversification/speciation by either dispersal or vicariance. In dispersal, a pre-existing barrier does not completely restrict gene flow, and colonists may move to a new area and form a new population. With time, the separated populations become distinct. The second pattern depends on vicariant events to explain taxon distributions. Under this model of diversification, the ancestor is widespread, and isolating (vicariant) events divide the ancestral population into sub-populations that can then differentiate in isolation (Ronquist 1997). These two explanations are not mutually exclusive, especially in highly vagile organisms like birds; therefore, teasing apart their relative influence on any one species can be problematic because either explanation can be equally parsimonious. However, comparative phylogeography across groups of taxa can help to provide insight into the most likely scenario of speciation.

Although a dispersal scenario cannot be entirely excluded, evidence from our niche modeling analyses and comparative phylogeographic studies point to a more important role for vicariance. The area of potential contact of the eastern and western Bell's Vireo clades (Fig. 1) has also been identified as a contact zone in previous studies of various organisms, many with similar dispersal abilities (Riddle and Hafner 2006; Shepherd and Burns 2007; Smith et al. 2011; Weyandt and Van Den Bussche 2007; Zink et al. 2001). A comparative study of co-distributed birds in the arid southwest of North America discovered that both the Canyon Towhee (Melozone fusca) and Curve-billed Thrasher (Toxostoma curvirostre) show sister relationships between the Sonoran and Chihuahuan deserts (Zink et al. 2001). Within the Northern Cardinal (Cardinalis cardinalis), Smith et al. (2011) also found a division of east and west sister taxa with a contact zone in eastern Arizona. Additional work on bats (Weyandt and Van Den Bussche 2007) provides further evidence of a similar pattern of differentiation in the dry deserts of southwest North America. Uplift in the late Neogene, from approximately 15-2 mya, produced the SMO, potentially isolating populations into Sonoran and Chihuahuan Desert sister taxa (Wilson et al. 2011). In the Pliocene and Pleistocene, after major landforms such as SMO had formed, three major filter-barriers in the warm deserts of North America had strong influences on the evolutionary history of organisms (Hafner and Riddle 2011). Among the three is the Cochise filter-barrier (Morafka 1977); it is located in the vicinity of the Deming Plains, an area in northwest Mexico near the Arizona/New Mexico border. The Cochise filter-barrier, like the SMO, may have isolated Bell's Vireo into eastern and western forms. Vicariance resulting from uplift and SMO formation in the late Neogene would require a deeper divergence than the 1 - 2 mya divergence identified for the western vs. eastern clades of Bell's Vireo. Instead, diversification due to the Cochise filter-barrier better aligns with the molecular dating, niche modeling results, and comparative phylogeography.

The two clades of Bell's Vireo correspond geographically and temporally with the same pattern of divergence as other highly vagile species in this region (Smith et al. 2011; Weyandt and Van Den Bussche 2007; Zink et al. 2001). In 
addition, niche modeling identified allopatric refugia for east and west populations during the LGM. During this time frame, riparian corridors (critical habitat for Bell's Vireo) would have been at their broadest and most connected (Hafner and Riddle 2011), yet two allopatric refugia were recovered. Therefore, the most likely explanation for the divergence in east and west populations is a result of glacial cycling and the Cochise filter-barrier.

\section{Conservation implications}

In this study, we present evidence for multiple species within the Bell's Vireo, and suggest a new taxonomy that better reflects the species' evolutionary history. Our findings reveal that within the context of conservation, Bell's Vireo is more appropriately considered not as one species with four subspecies, but as two species, each with two subspecies. This new information has implications for the federal, state and other listing status of Bell's Vireo throughout its range. Our results support the distinctiveness of the Least Bell's Vireo as a taxon and its recognition as state and federally endangered. A re-assessment of the conservation status of Bell's Vireo in the rest of the U.S. is warranted given that the new taxonomy will change the contexts within which abundance and distribution, threats, and management options for each species and subspecies are considered. Such a re-assessment, which might elevate the listing status of particular taxa or populations, is necessary to ensure that the full breadth of taxonomic diversity within Bell's Vireo is protected.

Genetic studies will continue to play a prominent role in providing necessary information for effective management of Bell's Vireo. Additional sampling both within and between Bell's Vireo and Least Vireo populations will provide clarification on the area of contact for the two species and allow for a better assessment of subspecies status. In particular, additional information is needed from the potential contact zone in New Mexico, where Bell's Vireo habitat is sparse and patchy. Similarly, further sampling to determine the boundary separating the Least and Arizona subspecies is necessary to resolve the taxonomic status of populations in eastern California, western Arizona and southern Nevada and thus identify which fall under the protection of the Endangered Species Act afforded to Least Bell's Vireo. Within California, where vireos occupy a highly urbanized and fragmented landscape, genetic analyses are needed to evaluate gene flow among drainages and the degree of genetic diversity within populations, an important determinant of their potential to respond to environmental change. Such analyses would establish whether Least Bell's Vireo populations are functioning as an inter-connected metapopulation, and reveal areas genetically isolated that would benefit from management action to re-connect them to other populations. Determination of the extent to which Least Bell's Vireo in coastal California is isolated by the Transverse Ranges from desert populations in eastern California would similarly provide information regarding genetic structuring and improve our ability to integrate evolutionary dynamics of populations into conservation strategies.

Acknowledgments We thank the scientific collectors, collection managers, staff, and curators at the following institutions that made tissue samples and museum skins available for this research: The Academy of Natural Sciences; Louisiana State University Museum of Natural Science; San Diego Natural History Museum; SDSU Museum of Biodiversity; Museum of Vertebrate Zoology, University of California, Berkeley; University of Washington Burke Museum; University of Kansas Natural History Museum; Field Museum of Natural History; United States Geological Survey; University of California, Los Angeles: Conservation Resource Center; The Institute for Bird Populations; Marjorie Barrick Museum, University of Nevada Las Vegas; Museum of Zoology, University of Michigan; Museum of Southwestern Biology, University of New Mexico; Carnegie Museum of Natural History; and Cara Joos (University of Missouri). This research was made possible by funding from: Frank M. Chapman Memorial Fund of the American Museum of Natural History, American Ornithologists' Union Research Award, Los Angeles Audubon Society's Ralph W. Schreiber Ornithology Research Award, and SDSU Ted Cohn Evolutionary Biology Scholarship. We also recognize the following individuals for their help with various aspects of the project: Nicholas Mason, Allison Shultz, Shannon Walsh, Mike Harvey, Scott Taylor, Andrew Gottscho, Marshal Hedin, Philip Unitt, Suellen Lynn, Ryan Pottinger, John Klicka, Robert Zink, Paul Maier, Philip Pryde, and two anonymous reviewers. Any use of trade, product, or firm names is for descriptive purposes only and does not imply endorsement by the U.S. Government.

\section{Compliance with ethical standards}

Ethical approval This research and the resulting manuscript followed all ethical guidelines outlined for authors by Conservation Genetics. All work with animals was performed with relevant state and federal permits and was approved by the Institutional Animal Care and Use Committee of San Diego State University. Funding for this project was received from the following sources: American Ornithologists' Union, American Museum of Natural History, Los Angeles Audubon Society, and San Diego State University.

Open Access This article is distributed under the terms of the Creative Commons Attribution 4.0 International License (http://crea tivecommons.org/licenses/by/4.0/), which permits unrestricted use, distribution, and reproduction in any medium, provided you give appropriate credit to the original author(s) and the source, provide a link to the Creative Commons license, and indicate if changes were made.

\section{References}

Arbeláez-Cortés E, Roldán-Piña D, Navarro-Sigüenza AG (2014) Multilocus phylogeography and morphology give insights into the recent evolution of a Mexican endemic songbird: Vireo hypochryseus. J of Avian Biol 45:253-263 
Avise JC, Ball R (1990) Principles of genealogical concordance in species concepts and biological taxonomy. Oxf Surv in Evol Biol 7:45-67

Bandelt H-J, Forster P, Röhl A (1999) Median-joining networks for inferring intraspecific phylogenies. Mol Biol Evol 16:37-48

Baum DA, Shaw KL (1995) Genealogical perspectives on the species problem. In: Hoch P, Stevenson A (eds) Experimental and molecular approaches to plant biosystematics, vol 53. Missouri Botanical Garden, St. Louis, pp 289-303

Bivand R, Lewin-Koh N (2015) maptools: tools for reading and handling spatial objects. $\mathrm{R}$ package version $0.8-36$

Bivand R, Rundel C (2014) rgeos: interface to geometry engineopen source (GEOS). R package version 0.3-8

Brown JL, Knowles LL (2012) Spatially explicit models of dynamic histories: examination of the genetic consequences of Pleistocene glaciation and recent climate change on the American Pika. Mol Ecol 21:3757-3775

Cadena CD, Klicka J, Ricklefs RE (2007) Evolutionary differentiation in the Neotropical montane region: molecular phylogenetics and phylogeography of Buarremon brush-finches (Aves, Emberizidae). Mol Phylogen Evol 44:993-1016

Collins WD et al (2006) The community climate system model version 3 (CCSM3). J Climate 19:2122-2143

Coues E (1866) Prodrome of a work on the ornithology of Arizona Territory. Merrihew \& Sons, Philadelphia

Coues E (1890) Key to North American birds, 4th edn. Estes and Lauriat, Boston

Darriba D, Taboada GL, Doallo R, Posada D (2012) jModelTest 2: more models, new heuristics and parallel computing. Nat Methods 9:772

Drummond AJ, Rambaut A (2007) BEAST: Bayesian evolutionary analysis by sampling trees. BMC Evol Biol 7:214

Earl DA (2012) STRUCTURE HARVESTER: a website and program for visualizing STRUCTURE output and implementing the Evanno method. Conserv Genet Resour 4:359-361

Elshire RJ, Glaubitz JC, Sun Q, Poland JA, Kawamoto K, Buckler ES, Mitchell SE (2011) A robust, simple genotyping-by-sequencing (GBS) approach for high diversity species. PLoS ONE 6:e19379

Evanno G, Regnaut S, Goudet J (2005) Detecting the number of clusters of individuals using the software STRUCTURE: a simulation study. Mol Ecol 14:2611-2620

Excoffier L, Laval G, Schneider S (2005) Arlequin (version 3.0): an integrated software package for population genetics data analysis. Evol Bioinform Online 1:47

Farrington HL, Lawson LP, Clark CM, Petren K (2014) The evolutionary history of Darwin's finches: speciation, gene flow, and introgression in a fragmented landscape. Evolution 68:2932-2944

Franzreb KE (1989) Ecology and conservation of the endangered least Bell's vireo. FWS-89 (1). Fish and Wildlife Service, Sacramento $\mathrm{CA}$

Gill FB (2014) Species taxonomy of birds: which null hypothesis? Auk 131:150-161

Goldwasser S, Gaines D, Wilbur SR (1980) The least Bell's Vireo in California: a de facto endangered race. American Birds 34:742-745

Greaves J, Chadwick L (2006) Apparent eastern Bell's Vireo in San Francisco. Western Birds 37:119-222

Guindon S, Gascuel O (2003) A simple, fast, and accurate algorithm to estimate large phylogenies by maximum likelihood. Syst Biol 52:696-704

Hackett SJ (1996) Molecular phylogenetics and biogeography of tanagers in the genus Ramphocelus (Aves). Mol Phylogen Evol 5:368-382

Hafner D, Riddle B (2011) Boundaries and barriers of North American warm deserts: an evolutionary perspective. In: Upchurch CSC, McGowan P, Slater AJ (eds) Palaeogeography and Palaeobiogeography: biodiversity in Space and Time. CRC Press, Boca Raton, pp 75-114

Haig SM, D'elia J, Winker K, Haig S (2010) Avian subspecies and the US endangered species act. Ornithol Monogr 67:24-34

Hart KM, Hunter ME, King TL (2014) Regional differentiation among populations of the Diamondback terrapin (Malaclemys terrapin). Conserv Genet 15:593-603

Hasumi H, Emori S (2004) K-1 coupled gcm (miroc) description. Center for Climate System Research, University of Tokyo, Tokyo

Hijmans RJ (2015) raster: Geographic data analysis and modeling. R package version 2.3-40

Hijmans RJ, Cameron SE, Parra JL, Jones PG, Jarvis A (2005) Very high resolution interpolated climate surfaces for global land areas. Int J Climatol 25:1965-1978

Jensen JL, Bohonak AJ, Kelley ST (2005) Isolation by distance, web service. BMC Genet 6:13

Johnson NK, Cicero C (2004) New mitochondrial DNA data affirm the importance of Pleistocene speciation in North American birds. Evolution 58:1122-1130

Klicka J, Spellman GM, Winker K, Chua V, Smith BT (2011) A phylogeographic and population genetic analysis of a widespread, sedentary North American bird: the Hairy Woodpecker (Picoides villosus). Auk 128:346-362

Kus B, Hopp SL, Johnson RR, Brown BT (2010) Bell's vireo (Vireo bellii), The Birds of North America Online. Ithaca: Cornell Lab of Ornithology http://bna.birds.cornell.edu/bna/species/035. Accessed 28 Mar 2014

Hijmans RJ, Phillips SJ, Leathwick J, J; E (2015) dismo: Species distribution modeling. $\mathrm{R}$ package version $1.0-12$

Lu F et al (2013) Switchgrass genomic diversity, ploidy, and evolution: novel insights from a network-based SNP discovery protocol. PLoS Genet 9:e1003215

Lynch M (2009) Estimation of allele frequencies from high-coverage genome-sequencing projects. Genetics 182:295-301

Manthey JD, Klicka J, Spellman GM (2011) Isolation-driven divergence: speciation in a widespread North American songbird (Aves: Certhiidae). Mol Ecol 20:4371-4384

Manthey J, Klicka J, Spellman G (2015) Chromosomal patterns of diversity and differentiation in creepers: a next-gen phylogeographic investigation of Certhia americana. Heredity 115:165-172

Mayr E (1993) Fifty years of progress in research on species and speciation. Proc Calif Acad Sci 48:131-140

Morafka DJ (1977) A biogeographical analysis of the Chihuahuan Desert through its herpetofauna. Dr. W Junk Publishers, The Hague

Owens HL et al (2013) Constraints on interpretation of ecological niche models by limited environmental ranges on calibration areas. Ecol Model 263:10-18

Posada D (2008) jModelTest: phylogenetic model averaging. Mol Biol Evol 25:1253-1256

Pritchard JK, Stephens M, Donnelly P (2000) Inference of population structure using multilocus genotype data. Genetics 155:945-959

Riddle BR, Hafner DJ (2006) A step-wise approach to integrating phylogeographic and phylogenetic biogeographic perspectives on the history of a core North American warm deserts biota. J Arid Environ 66:435-461

Ridgway R (1904) The Birds of North and Middle America: a descriptive catalogue of the higher groups, genera, species, and subspecies of birds known to occur in North America, from the Arctic Lands to the Isthmus of Panama, The West Indies and other islands of the Caribbean sea, and the Galapagos Archipelago. US National Museum Bulletin 50

Ronquist F (1997) Dispersal-vicariance analysis: a new approach to the quantification of historical biogeography. Syst Biol 46:195-203 
Sauer J, Hines E, Fallon J (2008) The North American breeding bird survey, results and analysis 1966-2007. Version 5.15.2008. USGS Patuxent Wildlife Research Laurel

Shepherd TM, Burns KJ (2007) Intraspecific genetic analysis of the summer tanager Piranga rubra: implications for species limits and conservation. J Avian Biol 38:13-27

Sibley DA (2014) The Sibley Guide to Birds, 2nd edn. Alfred A Knopf, New York

Slager DL, Battey CJ, Bryson J, Robert W, Voelker G, Klicka J (2014) A multilocus phylogeny of a major New World avian radiation: the Vireonidae. Mol Phylogen Evol 80:95-104

Smith BT, Escalante P, Baños BEH, Navarro-Sigüenza AG, Rohwer S, Klicka J (2011) The role of historical and contemporary processes on phylogeographic structure and genetic diversity in the Northern Cardinal. Cardinalis cardinalis. BMC Evol Biol 11:136

Stamatakis A (2014) RAxML version 8: a tool for phylogenetic analysis and post-analysis of large phylogenies. Bioinformatics 30:1312-1313

Swofford DL (2003) PAUP*. Phylogenetic analysis using parsimony (* and other methods). Version 4

Warren DL, Seifert SN (2011) Ecological niche modeling in Maxent: the importance of model complexity and the performance of model selection criteria. Ecol Appl 21:335-342

Weyandt SE, Van Den Bussche RA (2007) Phylogeographic structuring and volant mammals: the case of the pallid bat (Antrozous pallidus). J Biogeogr 34:1233-1245
White TA, Perkins SE, Heckel G, Searle JB (2013) Adaptive evolution during an ongoing range expansion: the invasive bank vole (Myodes glareolus) in Ireland. Mol Ecol 22:2971-2985

Wilson JS, Clark SL, Williams KA, Pitts JP (2011) Historical biogeography of the arid-adapted velvet ant Sphaeropthalma arota (Hymenoptera: Mutillidae) reveals cryptic species. J Biogeogr 39:336-352

Zink RM (2004) The role of subspecies in obscuring avian biological diversity and misleading conservation policy. Proc R Soc Lond B 271:561-564

Zink RM, McKitrick MC (1995) The debate over species concepts and its implications for ornithology. Auk 112:701-719

Zink RM, Kessen AE, Line TV, Blackwell-Rago RC (2001) Comparative phylogeography of some aridland bird species. The Condor 103:1-10

Zwartjes PW (1999) Genetic variability in the endemic vireos of Puerto Rico and Jamaica contrasted with the continental Whiteeyed Vireo. Auk 4:964-975

Zwartjes PW (2001) Genetic structuring among migratory populations of the black-whiskered vireo, with a comparison to the redeyed vireo. Condor 103:439-448

Zwartjes PW (2003) Genetic variability in migratory and endemic island songbirds (genus Vireo): a comparative assessment using molecular and morphological traits. Conserv Genet 4:749-758 